\title{
Prenatal Genetic Diagnostic Test Outcomes in Van Province and Nearby Cities in Eastern Turkey
}

\author{
Van ve Çevresinde Bulunan Türkiye'nin Doğu İllerindeki Prenatal Genetik Test Sonuçları
}

\author{
Emine GÖKTAŞ ${ }^{1}$ \\ (D) 0000-0002-3635-8763 \\ Reyhan AYAZ ${ }^{2}$ \\ (D) 0000-0002-2617-7918
}

${ }^{1}$ Van Regional Training and Research Hospital Department of Medical Genetics, Van, Turkey

${ }^{2}$ İstanbul Medeniyet University Faculty of Medicine Department of Perinatology, İstanbul, Turkey

\section{Corresponding Author Sorumlu Yazar \\ Emine GÖKTAŞ \\ emineaktas88@hotmail.com}

Received / Geliş Tarihi : 10.10.2019 Accepted / Kabul Tarihi : 22.01.2020 Available Online /

Çevrimiçi Yayın Tarihi : 25.04.2020

\begin{abstract}
Aim: The aim of this study is to retrospectively evaluate the indications and karyotype results of amniocentesis and chorion villus sampling performed in Health Sciences University, Van Education and Research Hospital, Department of Perinatology.

Material and Methods: In this study, 157 patients who underwent amniocentesis and 58 patients who performed chorion villus sampling procedure for different indications in our perinatology clinic between March 2017 and March 2019 were evaluated retrospectively. A spinal needle of 22-Gauge for amniocentesis procedure and a 20-Gauge spinal needle for chorionic villus sampling were used.

Results: Genetic abnormality was detected in $14.6 \%$ of amniocentesis $(n=23)$ and $34.5 \%$ of chorion villus sampling cases $(\mathrm{n}=20)$. Twenty $(87.0 \%)$ of the chromosomal anomalies detected in amniocentesis and $18(90.0 \%)$ of the anomalies detected in chorionic villus sampling were numerical anomalies. The most common chromosomal anomaly of these numerical anomalies was trisomy 21 . The most common indication for patients who underwent amniocentesis and chorionic villus sampling was abnormal ultrasound findings, followed by high risk in triple or quadruple test.

Conclusion: Amniocentesis and chorion villus sampling are commonly performed invasive tests for prenatal diagnosis of genetic diseases. The indications of amniocentesis and chorion villus sampling procedures and the rate of genetic anomaly detected as a result of genetic analysis applied to these samples in our clinic were compatible with literature. It is thought that this study will contribute to the literature since this is the first study that evaluates the results of amniocentesis and chorion villus sampling in Van and nearby cities.
\end{abstract}

Keywords: Amniocentesis; chorion villus sampling; chromosomal anomaly.

\section{ÖZ}

Amaç: Bu çalışmanın amacı, Sağlık Bilimleri Üniversitesi Van Eğitim ve Araştırma Hastanesi Perinatoloji Kliniğinde gerçekleştirilen amniyosentez ve koryon villus örneklemelerinin endikasyon ve karyotip sonuçlarının retrospektif olarak değerlendirilmesidir.

Gereç ve Yöntemler: Bu çalışmada, Mart 2017 ve Mart 2019 tarihleri arasında perinatoloji kliniğimizde çeşitli endikasyonlar ile amniyosentez uygulanan 157 hasta ve koryon villus örnekleme işlemi yapılan 58 hasta geriye dönük olarak incelendi. Amniyosentez işlemi için 22 Gauge spinal iğne ve koryon villus örneklemesi için ise 20 Gauge spinal iğne kullanıldı.

Bulgular: Amniyosentez yapılan olguların \%14,6'sında ( $n=23)$ ve koryon villus örneklemesi yapılan vakaların ise $\% 34,5$ 'inde $(n=20)$ genetik anomali saptandi. Amniyosentez sonucunda saptanan kromozom anomalilerinin 20'si (\%87.0) ve koryon villus örneklemesi sonucunda saptanan anomalilerin ise 18 ' $\mathrm{i}(\% 90,0)$ sayısal anomali idi. Bu sayısal anomaliler arasında en s1k saptanan kromozom anomalisi trizomi 21 idi. Amniyosentez ve koryon villus örneklemesi yapılan hastalarda en sık endikasyon anormal ultrason bulguları olup bu endikasyonu üçlü veya dörtlü testte risk yüksekliği takip etmekte idi.

Sonuç: Amniyosentez ve koryon villus örneklemesi, genetik hastalıkların prenatal tanısında sıklıkla kullanılan invaziv yöntemlerdir. Kliniğimizde amniyosentez ve koryon villus örnekleme endikasyonları ile örneklere uygulanan genetik analiz sonucu saptanan genetik anomali oranı literatür ile uyumlu idi. Bu çalışmanın, Van ve çevre illerdeki amniyosentez ve koryon villus örnekleme sonuçlarının değerlendirildiği ilk çalışma olması nedeniyle literatüre katkı sağlayacağı düşünülmektedir.

Anahtar kelimeler: Amniyosentez; koryon villus örneklemesi; kromozom anomalisi. 


\section{INTRODUCTION}

Invasive prenatal tests are crucial to detect genetic diseases during pregnancy (1). It provides genetic information to detect chromosomal anomalies found in the fetus in the early stages of pregnancy and enables the patients to decide on termination or birth of the fetus with the anomaly (2). There are indirect (non-invasive) methods including first trimester screening test (nuchal translucency (NT), free beta-hCG, PAPP-A), second trimester screening test (triple and quadruple screening tests) and fetal DNA determination on maternal circulation which form non-invasive techniques to determine the risk of genetic anomalies (3-5).

Chorionic villus sampling (CVS), amniocentesis and cordocentesis are performed in different gestational weeks to provide the precise diagnosis. CVS is performed between the $11^{\text {st }}$ and $14^{\text {th }}$ gestational weeks. CVS is a more preferable test over amniocentesis since it provides early diagnosis (6). Amniocentesis is the most frequently used prenatal invasive test to detect the fetal chromosomal anomalies. Although it is appropriate to perform amniocentesis between the $14^{\text {th }}$ and $22^{\text {nd }}$ weeks, the most suitable period for the process is between the $16^{\text {th }}$ and $17^{\text {th }}$ weeks at which culture success and fetal cell growth is the highest. Advanced maternal age, recurrent abortions, history of chromosome anomaly, stillbirth, parents with chromosome anomaly, high risk in maternal serum screening tests, abnormal ultrasound finding and family request are indications for amniocentesis. Even though prenatal invasive tests have some complications including amnion fluid leakage, vaginal bleeding, uterine contraction and fetal loss, it is known that complication rates are inversely proportional with experience of the clinicians and it is regarded as a reliable method with acceptable complication rate (7). Cordocentesis is another invasive method which is preferred after $21^{\text {st }}$ gestational week and the advantage of cordocentesis is that it provides early culture result and it can be used in late cases or in failed amniocentesis cases (1).

In this study, we evaluated indications, cytogenetic analysis and results of CVS and amniocentesis performed in the eastern of Turkey.

\section{MATERIAL AND METHODS}

In this study, data of 215 pregnant patients, who were admitted to the Perinatology Clinic of Health Sciences University, Van Education and Research Hospital from March 2017 to March 2019 and created the sampling of amniocentesis and chorion villus with various indications, was evaluated retrospectively. The data was examined with regard to indicative distribution and karyotype results of invasive procedures. Genetic counseling was given to all patients about the procedure before invasive operations. Ethic committee approval was taken from Van Education and Research Hospital, the approval number: 2019/07, date: 04.04.2019. Complications that may occur during and after the procedure were described to each patient and her husband, and written approval forms were signed by all couples. Detailed ultrasonographic evaluation including fetus biometric measurements, fetal heartbeat, and placenta localization was performed for all the patients before the procedure, and skin cleaning with povidone-iodine was provided before procedure as well. 10-15 microgram placenta sample was obtained using 1 Gauge spinal needle for CVS with the aid of the injector and transported to the transport medium. It was entered through the gestational sac from where it was the farthest to fetus and the largest to amniotic pocket with 22 Gauge sharp tip spinal needle in case of amniocentesis. The first aspirated amniotic fluid of $2 \mathrm{cc}$ expelled out in order to decrease maternal contamination risk; amniotic fluid was aspirated to 2 separate injectors at $1 \mathrm{cc}$ per pregnancy week. Both procedures were performed with USG-guidance. After these procedures, all patients were enable to listen to fetal heart beat; fetal viability was proven. Patients were monitored for possible complications after operation. Postprocessing rhogam practice was done to patients who had Rh incompatibility.

All fetal samples were sent to the Department of Medical Genetics for genetic examination under proper circumstances. Two cultures were made for each fetal sample and 2 preparations were prepared on average. The preparations were painted with $\mathrm{G}$ banding method with the aid of Giemsa and Trypsin, and in average 20 metaphases were examined for each sample on microscope and imaging system. Metaphases were examined by at least two analyzers; numerical and structural anomalies in chromosomes were named and recorded according to the International System for Human Cytogenetic Nomenclature (ISCN).

\section{Statistical Analysis}

Descriptive statistics were used to summarize the data, and given as mean \pm standard deviation, median (minimummaximum), and number (percentage). Statistical analyses were made using Excel 2019.

\section{RESULTS}

Invasive procedures were performed to 215 patients who were admitted to the Perinatology Clinic of Van Education and Research Hospital, Health Sciences University between March 2017 and March 2019. The amniocentesis was performed to 157 (73.0\%) patients and CVS to 58 $(27.0 \%)$ patients. Our patients were between the ages of $16-52$, and the mean age was $31.05 \pm 7.31$ years. Seventy three $(34.0 \%)$ of the patients were 35 years and older. While mean week of gestation was 17 weeks and 3 days (17.42 \pm 1.54$)$ in amniocentesis patients, it was 12 weeks and 4 days (12.57 \pm 0.95$)$ in CVS patients.

The indications for performing the invasive procedures were defined as increased risk in maternal serum screening tests, increase in NT, abnormal ultrasound findings and others (advanced maternal age, IUGR, history of baby chromosomal abnormality, family history). The indications for amniocentesis of the 157 patients analyzed were the presence of pathological findings in ultrasonography $(n=80,50.9 \%)$, high risk in triple or quadruple screening tests $(\mathrm{n}=46,29.3 \%)$, increased NT $(\mathrm{n}=11,7.0 \%)$, high risk in combined test $(\mathrm{n}=10,6.4 \%)$, and some other causes $(n=10,6.4 \%)$. Also, indications for the CVS were the presence of increased NT $(n=22,37.9 \%)$, pathological ultrasound findings $(n=21,36.2 \%)$, high risk in combined test $(n=12,20.7 \%)$ and other causes $(n=3$, $5.2 \%$ ). Data on the distribution of indications for amniocentesis and CVS were shown in Table 1. 
Table 1. Distribution of indications for amniocentesis and chorionic villus sampling, $\mathrm{n}(\%)$

\begin{tabular}{lcc}
\hline Indication & $\begin{array}{c}\text { Amniocentesis } \\
(\mathbf{n = 1 5 7})\end{array}$ & $\begin{array}{c}\text { CVS } \\
(\mathbf{n = 5 8})\end{array}$ \\
\hline High risk in combined test & $10(6.4)$ & $12(20.7)$ \\
High risk in triple or quadruple test & $46(29.3)$ & $0(0.0)$ \\
Increased NT thickness & $11(7.0)$ & $22(37.9)$ \\
Abnormal findings in ultrasound & $80(50.9)$ & $21(36.3)$ \\
Other & $10(6.4)$ & $3(5.1)$ \\
\hline CVS: Chorionic Villus Sampling, NT: Nuchal Translucency &
\end{tabular}

CVS: Chorionic Villus Sampling, NT: Nuchal Translucency

Chromosomal anomaly was detected in 43 (20.0\%) patients in total. Of these, $23(10.7 \%)$ patients were amniocentesis cases and $20(9.3 \%)$ patients were CVS cases.

Moreover, in our amniocentesis results, chromosomal anomaly was identified in $17(21.3 \%)$ of the 80 patients for whom the procedure was performed due to pathological USG finding; in $3(6.5 \%)$ of 46 patients who have high risk of triple or quadruple screening tests; in 2 (20.0\%) of 10 patients who have high combined risk; in $1(9.1 \%)$ of 11 patient who have increased NT thickness. In terms of chromosomal changes, numerical anomaly were detected in $20(87.0 \%)$ of 23 patients; only in $3(13.0 \%)$ of them had structural anomaly. Trisomy $21(\mathrm{n}=11,47.8 \%)$ was the most common numerical anomaly, followed by trisomy 18 $(\mathrm{n}=3 \mathrm{13} .0 \%$ ). Trisomy 13, triploidy, Turner Syndrome, structural changes belong to $\mathrm{X}$ chromosome were the other chromosomal abnormalities. Also, one patient was performed the ESCO2 gene analysis due to the presence of pathologic USG findings and diagnosed as Roberts Syndrome. Rates of chromosomal anomalies according to the indications for amniocentesis were shown in Table 2. In the CVS results; chromosomal anomaly was detected in $9(40.9 \%)$ of 22 patients for whom the invasive procedure was performed due to increased NT; in $8(38.1 \%)$ of 21 patients who had pathologic USG findings; in 2 (16.7\%) of 12 patients who had high risk of combined test; in 1 (33.3\%) of 3 patients who performed CVS due to other indications. In the $18(90.0 \%)$ of 20 patients having chromosomal changes, numerical anomaly was detected, but the rest of the patients $(n=2,10.0 \%)$ had structural anomaly. The most common numerical anomalies were trisomy $21(\mathrm{n}=5,25.0 \%)$ and trisomy $18(\mathrm{n}=3,15.0 \%)$ respectively, similar to the results of amniocentesis. Trisomy 13, trisomy 14, trisomy 7, triploidy, Turner syndrome and tetrasomy $12 \mathrm{p}$ were among the other chromosomal abnormalities. Rates of chromosomal anomalies according to the indications for CVS were shown in Table 3.

The amniocentesis and the CVS were performed successfully at the first attempt in 56 patients, at the second attempt in 2 patients. No patients needed more than two attempts. The sufficient placenta sample was obtained in all CVS patients at the first entry. There were not any complications after the both procedures. The karyotype results could not be obtained from two patients $(0.9 \%)$ performed CVS due to culture failure.

\section{DISCUSSION}

Prenatal diagnostic methods have been implemented since the 1950s in order to determine genetic anomalies during the pregnancy (8). Especially after 1980s, both CVS and amniocentesis have been performed under USG-guidance which also resulted in the increase in success rate of the processes $(9,10)$. While amniocentesis is the most frequently used invasive prenatal diagnostic method due to low complication rate and high culture reproduction success; the CVS is the gold standard of prenatal diagnosis in the first trimester which enables to detect the possible genetic disorders of the fetus in the earliest period $(11,12)$. The most common indications of CVS are; increased risk of first trimester screening test, increased NT, pathological USG findings, advanced maternal age, recurrent abortions in the family or a baby history with chromosomal anomaly $(12,13)$. The reliability of CVS is accepted as $99.5 \%$, but false negativity or positivity may be seen due to maternal contamination or placental mosaicism (14). Procedurerelated pregnancy loss, increased risk of extremity defect in early week procedures are the common complications of

Table 2. Distribution of karyotype results according to the indications for amniocentesis

\begin{tabular}{lccccc}
\hline Indication & Normal & Trisomy 21 & Trisomy 18 & Structural anomaly & Others \\
\hline High risk in combined test & $8(80.0)$ & $1(10.0)$ & $0(0.0)$ & $0(0.0)$ & $1(10.0)$ \\
High risk in triple or quadruple test & $43(93.5)$ & $2(4.3)$ & $0(0.0)$ & $0(0.0)$ & $1(2.2)$ \\
Increased NT thickness & $10(90.9)$ & $1(9.1)$ & $0(0.0)$ & $0(0.0)$ & $0(0.0)$ \\
Abnormal findings in ultrasound & $63(78.7)$ & $7(8.7)$ & $3(3.7)$ & $3(3.7)$ & $4(5.0)$ \\
Other & $10(100)$ & $0(0.0)$ & $0(0.0)$ & $0(0.0)$ & $0(0.0)$ \\
\hline
\end{tabular}

Table 3. Distribution of karyotype results according to the indications for chorionic villus sampling

\begin{tabular}{lccccc}
\hline Indication & Normal & Trisomy 21 & Trisomy 18 & Structural anomaly & Others \\
\hline High risk in combined test & $10(83.3)$ & $1(8.3)$ & $0(0.0)$ & $0(0.0)$ & $1(8.3)$ \\
Increased NT thickness & $13(59.1)$ & $3(13.6)$ & $1(4.5)$ & $1(4.5)$ & $4(18.2)$ \\
Abnormal findings in ultrasound & $13(61.9)$ & $1(4.8)$ & $2(9.5)$ & $1(4.8)$ & $4(19.0)$ \\
Other & $2(66.7)$ & $0(0.0)$ & $0(0.0)$ & $0(0.0)$ & $1(33.3)$ \\
\hline
\end{tabular}


CVS $(15,16)$. In our study, the most common CVS indication was the increase in NT (37.9\%), followed by the presence of pathological findings in USG (36.3\%), increased risk in the first trimester combined test (20.7\%) and some other reasons (5.1\%). Bilen et al. (12) in a study with 42 patient who performed CVS observed that the most common indication of the procedure was advanced maternal age $(33.3 \%)$ followed by increased risk in the first trimester screening test $(26.2 \%)$ and presence of abnormality in ultrasonography (19\%). In our study, maternal age over 35 was present in 12 of 58 patients who underwent CVS, but in these patients there were increased risk in the first trimester screening test or abnormal USG findings as well. Dağlar et al. (17) showed that increased risk of first trimester combined test $(80 \%)$ was the most common CVS indication followed by advanced maternal age (13.3\%). On the other hand, in a study of Oztas et al. (18) in the 354 patients who were performed CVS, increased risk of combined screening test (68.6\%) was the most common indication for the procedure; followed by the increase in NT $(19.2 \%)$.

Amniocentesis is the most commonly used invasive method in fetal genetic diagnosis. The indications of the procedure are the advanced maternal age, the increased risk results in maternal serum screening tests, pathological USG findings, history of having baby with the chromosomal anomaly, chromosomal anomaly in the parents and desire of the family (19). Although the most common indication is defined as the advanced maternal age in many studies, abnormal screening test result is the most common indication recently (20-23). This change about the indications was attributed to the increase in the reliability of screening tests and that the American Society of Obstetricians and Gynecologists (ACOG)'s January 2007 paper suggesting that screening tests should be performed for all pregnant women independent of the maternal age (24). In a study by Acar et al. (25) in 3721 amniocentesis cases, the most common indication was determined as the increased risk in maternal screening test (45.1\%), followed by advanced maternal age (35.8\%) and abnormal USG findings $(15.8 \%)$. On the other hand, Tasdemir et al. (26) reported that the advanced maternal age was the most common indication $(40.4 \%)$, whereas the increased risk in the maternal serum screening test was the second common indication (38.9\%) in a study with 1429 cases. Gündüz et al. (27) observed that the advanced maternal age, which is the most common indication for 4year prenatal cytogenetic studies, replaced its position to increased risk in triple testing in time. Similarly, the most common indication was found to be increased risk in triple screening tests in a study by Türkyılmaz et al. (28) that was performed in 481 patients. Furthermore, in a study by Serin et al. (29) that was performed in 561 cases, the most common indication was increased risk in triple screening tests $(65.59 \%)$, followed by abnormal ultrasound findings (14.26\%). In our study, presence of pathological finding in USG was the most common indication (50.9\%). This indication was followed by increased risk in triple test (29.3\%), increase in NT $(7.0 \%)$, increased risk in the combined test $(6.4 \%)$ and other causes (6.4\%). Similarly, the most common indication was found to be pathological finding $(29.4 \%)$ in USG in the study of Lostchuck et al. (30) that was performed in 16152 patients. The number of the patients who were performed invasive testing with indication of the advanced maternal age was not significantly high since most of these patients had also increased risk in screening tests or abnormal USG findings. Dilek et al. (31) applied to yield and cost analysis to the patients that underwent amniocentesis between the years of 2000-2005. It was emphasized that the efficacy of amniocentesis alone with advanced age indication was not enough; USG imaging and serum screening tests should be used together with this indication which supported our findings as well.

In our study, 134 of the patients had normal karyotype in total 157 cases that performed amniocentesis (85.4\%). Chromosomal anomaly was present in 23 of the patients; $20(87.0 \%)$ of them were numerical anomalies and 3 $(13.0 \%)$ of them were structural anomalies. Trisomy 21 is the most frequently chromosomal anomaly among numerical anomalies. Trisomy 18 and trisomy 13 followed this anomaly. In the studies which were reporting the results of amniocentesis, it was seen that chromosomal anomaly rate varies between $1.5 \%$ and $14.3 \%$ in the literature (32). Stoll et al. (33) and Eddleman et al. (34) mentioned in their studies that the frequency of chromosomal anomaly was increased in the presence of fetal anomaly varying the rates between $4 \%$ and $27 \%$. Fu et al. (35) showed that frequency of chromosomal anomaly was $18 \%$ in patients with pathologic findings in ultrasound while, this rate was reported as $27.1 \%$ in the study of Dallaire et al. (36). In our study, 80 of the patients of total 157 cases who were performed amniocentesis had abnormal findings in USG and high rate of chromosomal anomaly $(14.6 \%)$ correlates with the literature.

In this study, 38 of 58 CVS cases $(65.5 \%)$ had normal karyotype. Chromosomal anomaly was present in the 20 patients; 18 of them were numerical anomalies and 2 of them were structural anomalies. Trisomy 21 was the most common numerical chromosomal anomaly followed by trisomy 18, trisomy 13, triploidy, Turner Syndrome and trisomy 14. Daglar et al. (17) showed that the chromosomal anomaly rate was $26.6 \%$ in CVS cases and $20 \%$ of them had numerical anomaly. In the study by Bilen et al. (12) in 42 CVS cases, chromosomal anomaly rate was reported as $35.7 \%$, and the most common anomaly was trisomy 21 in $53.5 \%$ of the cases.

As a result; in our study the abnormal karyotype rate was $14.6 \%$ in 157 amniocentesis samples, and $34.5 \%$ in 58 CVS samples. There were no false negative or false positive results. Maximum two attempts were performed to the patients; thus, sufficient amniotic fluid and placenta samples were obtained. Fetal loss occurred in one patient who were performed CVS had also hydrops fetalis during the procedure. In our study, it was determined that abortion rate after CVS was $1.7 \%$ which is similar to the literature and there was not any complication after amniocentesis (16). Recently, some methods such as fetal DNA screening in the maternal blood have been developed and they are recommended to be used to detect fetal chromosomal anomalies. However, this cell free DNA testing (NIPT) can only be used as a screening test (37), and invasive tests are required for confirmation of the result (38). This is the first study analyzing the data of Van and nearby cities on the amniocentesis and CVS results and we thought that it will shed light on future studies. 


\section{REFERENCES}

1. Nussbaum RL, McInnes RR, Willard HF. Thompson and Thompson genetics in medicine. 6th ed. Philadelphia: Saunders; 2001.

2. Aksoy S. Antenatal screening and its possible meaning from unborn baby's perspective. BMC Med Ethics. 2001;2:E3.

3. Suciu I, Galeva S, Abdel Azim S, Pop L, Toader O. First-trimester screening-biomarkers and cell-free DNA. J Matern Fetal Neonatal Med. 2019;[Epub ahead of print]. doi: 10.1080/14767058.2019.1698031.

4. Aghaz F, Ojagh SZ, Khanjari S, Vaisi-Raygani A, Khazaei M, Bakhtiari M. The contingent prenatal screening test for down's syndrome and neural tube defects in west of Iran. J Reprod Infertil. 2019;20(4):244-51.

5. Chen Y, Yu Q, Mao X, Lei W, He M, Lu W. Noninvasive prenatal testing for chromosome aneuploidies and sub-chromosomal microdeletions/microduplications in a cohort of 42,910 single pregnancies with different clinical features. Hum Genomics. 2019;13(1):60.

6. Alfirevic $Z$, Navaratnam $K$, Mujezinovic $F$. Amniocentesis and chorionic villus sampling for prenatal diagnosis. Cochrane Database Syst Rev. 2017;9:CD003252.

7. Cederholm M, Haglund B, Axelsson O. Maternal complications following amniocentesis and chorionic villus sampling for prenatal karyotyping. BJOG. 2003;110(4):392-9.

8. Carlson LM, Vora NL. Prenatal diagnosis: screening and diagnostic tools. Obstet Gynecol Clin North Am. 2017;44(2):245-56.

9. Schmidt W, Gabelmann J, Müller U, Voigtländer T, Hager HD, Schroeder TM, et al. Genetic amniocentesis: technique and results in 1,000 first trimester amniocentesis. Geburtshilfe Frauenheilkd. 1980;40(9):761-8.

10. Kazy Z, Rozovsky IS, Bakharev VA. Chorion biopsy in early pregnancy: a method of early prenatal diagnosis for inherited disorders. Prenat Diagn. 1982;2(1):39-45.

11. Odabaşı AR, Yüksel H, Demircan Sezer S, Temoçin K, Bal F, Yapic1 S, et al. The results of second trimester genetic amniocentesis procedure: Adnan Menderes University experience with the results of 22 centers in Turkey. Türkiye Klinikleri J Gynecol Obst. 2007,17(3):196-206.

12. Bilen E, Yüksel M, Sezik M, Köse SA, Tola EN. Chorion villus sampling for karyotyping at 11-14 weeks of gestation: Evaluation of 42 cases. SDÜ Sağlık Bilimleri Dergisi. 2015;6(1):1-3.

13. Öztürk FH, Öcal FD, Erol SA, Yakut K, Öztürk M, Oguz Y, et al. Fetal genetic diagnosis by chorionic villus sampling: evaluation of the five-year experience from a single center. Fetal Pediatr Pathol. 2020;[Epub ahead of print]. doi: 10.1080/15513815.2019.1707919.

14. Spencer K, Spencer CE, Power M, Dawson C, Nicolaides KH. Screening for chromosomal abnormalities in the first trimester using ultrasound and maternal serum biochemistry in a one-stop clinic: a review of three years prospective experience. BJOG 2003;110(3):281-6.
15. Medical Research Council European trial of chorion villus sampling. MRC working party on the evaluation of chorion villus sampling. Lancet. 1991;337(8756):1491-9.

16. Akolekar R, Beta J, Picciarelli G, Ogilvie C, D'Antonio F. Procedure-related risk of miscarriage following amniocentesis and chorionic villus sampling: a systematic review and meta-analysis. Ultrasound Obstet Gynecol. 2015;45(1):16-26.

17. Dağlar HK, Kaya B, Şahin HÖ, Pınar MF, Akıl A. Retrospective analysis of 268 cases of amniocentesis and chorion villus sampling. Perinatal Journal. 2011;19(3):130-6.

18. Öztaş E, Özler S, Bakır A, Savaşçığlu Keskin İ, Uygur D. Results and experience of CVS in our clinic: three years analysis. İKSST Derg. 2016;8(2):81-7.

19. Tseng JJ, Chou MM, Lo FC, Lai HY, Chen MH, Ho ES. Detection of chromosome aberrations in the second trimester using genetic amniocentesis: experience during 1995-2004. Taiwan J Obstet Gynecol. 2006;45(1):39-41.

20. Şener KT, Durak B, Tanır HM, Tepeli E, Kaya M, Artan S. Amniocentesis results in 7 years period in our clinic. Perinatal Journal. 2006;14(4):170-5.

21. Yüce H, Çelik H, Gürateş B, Erol D, Hanay F, Elyas H. Retrospective analysis of 356 amniocentesis results performed for karyotype analysis. Perinatal Journal. 2006;14(2):73-6.

22. Yang YH, Ju KS, Kim SB, Cho YH, Lee JH, Lee SH, et al. The Korean collaborative study on 11,000 prenatal genetic amniocentesis. Yonsei Med J. 1999;40(5):460-6.

23. Andrew C, Koshy T, Gopal S, Paul SFD. A retrospective exploratory study of fetal genetic invasive procedures at a University Hospital. J Obstet Gynaecol. 2018;38(7):906-10.

24. ACOG Committee on Practice Bulletins. ACOG Practice Bulletin No. 77: screening for fetal chromosomal abnormalities. Obstet Gynecol. 2007;109(1):217-27.

25. Acar A, Ercan F, Yildirim S, Görkemli H, Gezginç K, Balcı O, et al. Genetic amniocentesis results: analysis of the 3721 cases. Med Bull Sisli Etfal Hosp. 2016;50(1):33-8.

26. Taşdemir Ş, Yılmaz M, Şahin İ, Erdem HB, Al RA, İngeç $\mathrm{M}$, et al. Retrospective analysis of 1429 cases who underwent amniocentesis and cordocentesis. Perinatal Journal. 2014;22(3):138-41.

27. Gunduz C, Cogulu O, Cankaya T, Bora E, Karaca E, Alpman A, et al. Trends in cytogenetic prenatal diagnosis in a reference hospital in İzmir/Turkey: a comparative study for four years. Genetic Couns. 2004;15(1):53-9.

28. Türkyılmaz A, Alp MN, Budak T. Prenatal genetic diagnosis in 481 amniocentesis, chorion villi sample and cordocentesis specimens. Dicle Med J. 2007;34(3):187-90.

29. Serin S, Arıkan DC. Amniocentesis results and retrospective analysis performed in the university clinic. Perinatal Journal. 2013;21(2):47-52.

30. Lostchuck E, Poulton A, Halliday J, Hui L. Populationbased trends in invasive prenatal diagnosis for ultrasound- 
based indications: two decades of change from 1994 to 2016. Ultrasound Obstet Gynecol. 2019;53(4):503-11.

31. Dilek TUK, Pata Ö, Yazıcı G, Arslan M, Tok E, Çayan $\mathrm{F}$, et al. Results and cost-effectiveness analysis of genetic amniocentesis between the 2000 and 2005. J Turk Ger Gynecol Assoc. 2005;6(4):285-9.

32. Turhan NO, Eren U, Seckin NC. Second-trimester genetic amniocentesis: 5-year experience. Arch Gynecol Obstet. 2005;271(1):19-21.

33. Stoll C, Dott B, Alembik Y, Roth MP. Evalution of routine prenatal ultrasound examination in detecting fetal chromosomal abnormalities in a low risk population. Hum Genet. 1993;91(1):37-41.

34. Eddleman KA, Malone FD, Sullivan L, Dukes K, Berkowitz RL, Kharbutli Y, et al. Pregnancy loss rates after midtrimester amniocentesis. Obstet Gynecol. 2006;108(5):1067-72.

35. Fu F, Li R, Li Y, Nie ZQ, Lei T, Wang D, et al. Whole exome sequencing as a diagnostic adjunct to clinical testing in fetuses with structural abnormalities. Ultrasound Obstet Gynecol. 2018;51(4):493-502.

36. Dallaire L, Michaud J, Melancon SB, Potier M, Lambert M, Mitchell G, et al. Prenatal diagnosis of fetal anomalies during the second trimester of pregnancy: their characterization and delineation of defects in pregnancies at risk. Prenat Diagn. 1991;11(6):629-35.

37. Geppert J, Stinton C, Johnson S, Clarke A, Grammatopoulos D, Taylor-Phillips S. Antenatal screening for fetal trisomies using microarray-based cell-free DNA testing: A systematic review and metaanalysis. Prenat Diagn. 2019; [Epub ahead of print]. doi: $10.1002 /$ pd.5621.

38. Goldwaser T, Klugman S. Cell-free DNA for the detection of fetal aneuploidy. Fertil Steril. 2018;109(2):195-200. 